\title{
KONSEKUENSI HUKUM BAGI SUAMI YANG MELAKSANAKAN POLIGAMI YANG MELANGGAR ATURAN HUKUM POSITIF INDONESIA DAN HUKUM ISLAM
}

\author{
Dian Septiandani, Dhian Indah Astanti \\ Fakultas Hukum Universitas Semarang, Semarang \\ dian.septiandani@usm.ac.id
}

\begin{abstract}
Abstrak
Tujuan penelitian ini adalah untuk mengetahui konsekuensi hukum bagi suami yang melaksanakan poligami yang melanggar aturan hukum positif Indonesia dan hukum Islam. Pada prinsipnya, hukum perkawinan di Indonesia berasaskan monogami. Akan tetapi perkawinan poligami dalam Islam tidak dilarang dan diakomodir oleh pemerintah dalam Undang-undang Perkawinan. Dalam Islam diperbolehkan seorang suami melakukan poligami dan tidak menentukan persyaratan apapun secara tegas, kecuali hanya memberikan syarat kepada suami untuk berlaku adil, sedangkan dalam Undang-undang Perkawinan seorang suami yang ingin poligami harus memenuhi syarat alternatif dan syarat komulatif yang telah diatur oleh undang-undang. Berdasarkan hal tersebut penelitian ini menjadi sangat penting untuk dilakukan guna menemukan konsekuensi hukum bagi suami yang melaksanakan poligami yang melanggar aturan hukum positif Indonesia dan hukum Islam. Penelitian ini merupakan penelitian hukum normatif dengan menggunakan pendekatan perundang-undangan dan pendekatan perbandingan.. Hasil penelitian menunjukkan bahwa apabila ditinjau dari hukum positif, konsekuensi seorang suami yang melaksanakan poligami yang melanggar aturan hukum yakni perkawinan dianggap batal demi hukum sehingga perkawinan tersebut tidak memiliki kekuatan hukum, istri pertama dapat membatalkan perkawinan, serta suami dapat dijatuhi pidana. Sedangkan dalam hukum islam, hukumnya haram apabila suami yang berpoligami tidak berlaku adil serta melebihi dari empat istri.
\end{abstract}

Kata kunci: Konsekuensi; Poligami; Hukum Positif; Hukum Islam

\section{LEGAL CONSEQUENCES FOR HUSBANDS WHO PRACTICE POLYGAMY THAT VIOLATES THE RULES OF POSITIVE INDONESIAN LAW AND ISLAMIC LAW}

\begin{abstract}
The purpose of this research is to find legal consequences for husbands who practice polygamy that violates the rules of positive Indonesian law and Islamic law. In principle, marriage law in Indonesia is based on monogamy. However, polygamous marriages in Islam are not prohibited and are accommodated by the government in the Marriage Law. In Islam, it is permissible for a husband to practice polygamy and not specify any conditions explicitly, except only to provide conditions for the husband to act fairly, while in the Marriage Law a husband who wants polygamy must meet the alternative and cumulative conditions that have been regulated by law. Based on this, this research is very important to do in order to find legal consequences for husbands who practice polygamy that violates the rules of positive Indonesian law and Islamic law. This research is normative legal research using a statutory approach and a comparative approach. The results show that when based on a positive law perspective, the consequence of a husband who practices polygamy that violates the rule of law is that the marriage is considered null and void so that the marriage has no legal force, the first wife can cancel the marriage, and the husband can be punished. Whereas in Islamic law, the law is forbidden if a polygamous husband does not act fairly and exceeds four wives.
\end{abstract}

Keywords: Consequences; Polygamy; Positive Law; Islamic Law 


\section{A. PENDAHULUAN}

Berdasarkan ketentuan Pasal 1 Undang-Undang No. 1 Tahun 1974 sebagaimana telah diubah oleh Undang-Undang Nomor 16 Tahun 2019 tentang Perkawinan (selanjutnya disebut UU Perkawinan) perkawinan "ialah ikatan lahir bathin antara seorang pria dengan seorang wanita sebagai suami isteri dengan tujuan membentuk keluarga (rumah tangga) yang bahagia dan kekal berdasarkan Ketuhanan Yang Maha Esa". Pada prinsipnya dalam pasal tersebut, hukum Perkawinan Indonesia berasaskan monogami. Kamus Besar Bahasa Indonesia menggunakan istilah "istri” yang artinya ialah "wanita (perempuan) yang telah menikah atau bersuami". Wanita yang dinikahi (kbbi.web.id), dan tidak ditemukan kata "isteri". Namun di dalam Undangundang Perkawinan, kata yang digunakan adalah "isteri”. Dalam hal penulisan isi pasal, penelitian ini tetap menggunakan kata "isteri”, sedangkan di luar penulisan isi pasal dalam perundang-undangan, maka menggunakan kata "istri".

Asas monogami lebih ditegaskan lagi di dalam bunyi Pasal 3 ayat (1) UU Perkawinan yang mengatakan bahwa pada asasnya dalam suatu perkawinan seorang pria hanya boleh mempunyai seorang isteri. Di mana seorang wanita hanya boleh mempunyai seorang suami. Hal ini berarti sebenarnya yang dianjurkan oleh undang-undang adalah perkawinan monogami. Meskipun UU Perkawinan pada asasnya adalah perkawinan monogami, namun negara memperbolehkan bagi seorang suami untuk beristeri lebih dari seorang (poligami). Poligami (dalam Kamus Besar Bahasa Indonesia, digunakan istilah "poligami", sedangkan UU Perkawinan menggunakan istilah "beristeri lebih dari seorang") merupakan sistem perkawinan yang salah satu pihak memiliki atau mengawini beberapa lawan jenisnya dalam waktu yang bersamaan. ${ }^{1}$

Aturan hukum diperbolehkan poligami terdapat dalam Pasal 3 ayat (1) UU Perkawinan, dimana pengadilan dapat memberi izin kepada seorang suami untuk beristeri lebih dari seorang apabila dikehendaki oleh pihak yang bersangkutan. Dalam hal seorang suami akan beristeri lebih dari seorang, maka ia wajib mengajukan permohonan kepada pengadilan di daerah tempat tinggalnya (Pasal 4 ayat 1 UU Perkawinan), serta Kompilasi Hukum Islam.

Tujuan Kompilasi Hukum Islam adalah unifikasi hukum Islam yang diberlakukan bagi umat Islam menurut kondisi dan kebutuhan hukum masyarakat Islam Indonesia. Unifikasi hukum Islam tersebut dilakukan berlandaskan atas pemikiran hukum para ahli hukum Islam tentang perlunya transformasi hukum Islam kedalam hukum positif, sehingga tercipta keseragaman pelaksanaan hukum Islam dalam mengatasi masalahmasalah kehidupan ummat Islam dalam bidang mu'amalah. ${ }^{2}$

Perkawinan poligami dalam Islam tidak dilarang dan diakomodir oleh pemerintah dalam UU Perkawinan. Dalam Islam, poligami diatur dalam Quran Surat An Nisa' ayat (3), yang berbunyi: "Dan jika kamu khawatir tidak akan mampu berlaku adil terhadap (hak-hak) perempuan yatim (bilamana kamu menikahinya), maka nikahilah perempuan

\footnotetext{
${ }^{1}$ KBBI Online, "Kamus Besar Bahasa Indonesia," n.d., https://kbbi.web.id/.

2 Azni Azni, "Izin Poligami Di Pengadilan Agama (Suatu Tinjauan Filosofis)," Jurnal Dakwah Risalah 26, no. 2 (2015): 55-68, https://doi.org/10.24014/jdr.v26i2.1214.
} 
(lain) yang kamu senangi: dua, tiga, atau empat. Tetapi jika kamu khawatir tidak akan mampu berlaku adil, maka (nikahilah) seorang saja atau hamba sahya perempuan yang kamu miliki. Yang demikian itu lebih dekat agar kamu tidak berbuat dzalim". Ayat tersebut merupakan pengaturan mengenai perkawinan poligami, sekaligus monogami. Allah memperbolehkan seorang suami menikah lagi, namun tetap harus memperhatikan kemampuan untuk berlaku adil. Apabila tidak dapat berlaku adil, maka diminta menikahi seorang wanita saja. Allah maha mengetahui kemampuan hambaNya.

Islam diperbolehkan seorang suami melakukan poligami dan tidak menentukan persyaratan apapun secara tegas, kecuali hanya memberikan syarat kepada suami untuk berlaku adil, sedangkan dalam UU Perkawinan seorang suami yang ingin poligami harus memenuhi syarat alternatif dan syarat komulatif yang telah diatur oleh Undang-Undang tersebut. ${ }^{3}$

Pasal 5 ayat (1) dan (2) UU Perkawinan, laki-laki harus mendapat persetujuan dari istri atau istri-istrinya untuk berpoligami. UU Perkawinan mensyaratkan bagi laki-laki yang ingin berpoligami harus memenuhi syarat kumulatif dan alternatif serta mendapat izin dari pengadilan agama setempat. Pasal 4 ayat (2) UU Perkawinan berbunyi pengadilan hanya akan memberikan izin kepada suami yang ingin beristri lagi apabila; Istri tidak dapat menjalankan kewajibannya sebagai istri, Istri mendapat cacat badan atau penyakit yang tidak dapat disembuhkan, Istri tidak dapat melahirkan keturunan. Syarat yang tersebut pada Pasal 4 ayat (2) UU Perkawinan merupakan syarat alternatif, artinya apabila terpenuhi salah satu dari ketiga point tersebut, suami dapat mengajukan izin poligami.

Tidak ditentukannya syarat persetujuan isteri tersebut, di dalam Islam ada perbedaan pendapat di antara para ulama. Dimana ada pendapat yang menentukan bahwa persetujuan merupakan syarat mutlak. Ada yang menentukan, bahwa poligami tanpa persetujuan isteri sebelumnya adalah sah, asal terpenuhi rukun dan syarat perkawinan. Sedangkan di dalam syarat dan rukun perkawinan itu sendiri, memang tidak ada unsur persetujuan isteri atau isteri-isteri sebelumnya.

Bahkan tanpa diketahui atau dihadiri isteri atau isteri-isteri sebelumnya sekalipun. Istri adalah warga negara yang secara konstitusi harus dilindungi tanpa ada diskriminasi, yaitu dengan terjaminnya perlindungan : 1.Agama ( (hifdl al-din) 2. Kehidupan/ Jiwa ( al-nafs) 3. Kebutuhan intelektual / akal (al-aql) 4. Keturunan (al-nasl) dan 5. Harta/kekayaan (al-mal)(Maqashid Syariah)( Maqashid Al Syariah yaitu tujuan-tujuan dan rahasia-rahasia yang diletakkan Allah dan terkandung dalam setiap hukum untuk keperluan pemenuhan manfaat umat. Atau tujuan dari Allah menurunkan syari'at. Dikemukakan dan dikembangkan oleh Abu Ishaq Al-Syathibi. ${ }^{4}$

Dalam hal ini, negara pun wajib memberikan perlindungan yang sama bagi seluruh warga negaranya. Meskipun perkawinan merupakan hak pribadi setiap manusia, namun

\footnotetext{
${ }^{3}$ Nur Shofa Ulfiyati, "Izin Isteri Sebagai Syarat Poligami Perspektif Hak Asasi Manusia : Kajian Terhadap Undang-Undang Perkawinan" 8, no. 2 (2016): 97-112.

4 Abd Shomad, Hukum Islam: Penormaan Prinsip Syariah Dalam Hukum Indonesia. (Jakarta: Kencana Prenada Media Group., 2010).
} 
dengan adanya pengaturan di dalam perundang-undangan, negara sedang menjalankan perannya.

Menurut ahli sejarah, pada awalnya poligami dilakukan oleh raja-raja pembesar negara dan orang-orang berharta. Mereka mengambil lebih dari satu wanita, ada yang dikawini dan ada pula yang hanya dipergunakan untuk melampiaskan hawa nafsunya dan keinginan bilogisnya. Perang yang terjadi pada waktu itu menjadikan banyak anak gadis yang diperjualbelikan, diambil sebagai pelayan, kemudian dijadikan wanita simpanan dan sebagainya. Semakin kaya seseorang dan tinggi kedudukanya, semakin banyak juga dia memiliki wanita. Dengan demikian, poligami pada waktu itu lebih kearah penindasan terhadap para wanita oleh orang-orang yang berharta dan bertahta. ${ }^{5}$ Untuk saat ini, jangan sampai terjadi lagi poligami yang menindas dan menyakiti, diperlukan peran negara dalam melindungi hak istri.

Penelitian sebelumnya yang mengkaji tentang poligami pernah diteliti oleh Roslinda, et al (2019) yang berjudul "Penerapan Sanksi Pidana Terhadap Pelaku Perkawinan Poligami Dalam Persfektif Perundang-Undangan Indonesia". Berdasarkan asas tiada pidana tanpa kesalahan (geen straf zonder schuld, actus non facit nisi mens sit rea). menyatakan pidana hanya diberikan kepada orang yang bersalah, asas ini ada dalam hukum yang tidak tertulis dan hidup serta berkembang dalam anggapan masyarakat. Penelitian ini mengkaji mengenai penerapan sanksi pidana terhadap pelaku perkawinan poligami dalam perspektif perundang-undangan Indonesia dan hambatan dalam penerapan sanksi pidana terhadap pelaku perkawinan poligami. ${ }^{6}$

Penelitian lainnya yang mengkaji mengenai poligami ditulis oleh Rizkal (2019) yang berjudul "Poligami Tanpa Izin Isteri Dalam Perspektif Hukum: Bentuk Kekerasan Psikis Terhadap Isteri”. Penelitian tersebut fokus utamanya yaitu izin istri dimana satu dari syaratnya ada persetujuan atau izin dari istri pertama yang dibuat secara tertulis. Poligami tanpa izin istri pertama akan menimbulkan konflik dalam rumah tangga yaitu kekerasan psikis konflik yang dialami oleh istri. Sehingga sang istri akan meminta cerai karena merasa dikhianati suami. Dalam keadaan seperti itu, istri akan merasa sangat dirugikan dengan tindakan poligami secara diam-diam gangguan psikologis akibat pengkhianatan oleh suami. ${ }^{7}$

Sedangkan penelitian mengenai poligami lainnya ditulis oleh Ardhian et al., (2015) dalam penelitiannya yang berjudul "Poligami Dalam Hukum Islam Dan Hukum Positif Indonesia Serta Urgensi Pemberian Izin Poligami Di Pengadilan Agama", membahas mengenai pengadilan agama yang merupakan lembaga peradilan dibawah Mahkamah Agung yang sangat penting dalam menangani permasalahan mengenai sengketa yang berhubungan dengan agama Islam. Mulai dari perkawinan, kewarisan, wasiat, hibah,

5 M A Mustofa, "Poligami Dalam Hukum Agama Dan Negara," AL-IMARAH: Jurnal Pemerintahan Dan Politik Islam 2, no. 01 (2017): 47-58, https://ejournal.iainbengkulu.ac.id/index.php/alimarah/article/view/1029.

${ }^{6}$ Sri Roslinda, Bunyamin Alamsyah, and Fredricka Nggeboe, "Penerapan Sanksi Pidana Terhadap Pelaku Perkawinan Poligami Dalam Persfektif Perundang-Undangan Indonesia," Legalitas: Jurnal Hukum 11, no. 1 (2019): 27, https://doi.org/10.33087/legalitas.v11i1.168.

${ }^{7}$ Rizkal Rizkal, "Poligami Tanpa Izin Isteri Dalam Perspektif Hukum: Bentuk Kekerasan Psikis Terhadap Isteri," Jurnal Yustika: Media Hukum Dan Keadilan 22, no. 01 (2019): 26-36, https://doi.org/10.24123/yustika.v22i01.2017. 
wakaf, zakat, infak, sedekah, sampai ekonomi syariah menjadi tugas dan wewenang dari pengadilan agama yang sesuai dengan Pasal 49 dan 50 UU No. 7 Tahun 1989 tentang Pengadilan Agama yang telah diamandemen dengan UU No. 3 Tahun 2006. Dalam Pasal 4 ayat (1) UU No. 1 Tahun 1974 tentang Perkawinan, apabila seorang suami ingin beristri lebih dari seorang maka wajib mengajukan permohonan kepada pengadilan di daerah tempat tinggalnya (yaitu pengadilan agama). Diatur pula dalam pasal-pasal berikutnya dalam pengajuan poligami harus memenuhi syarat-syarat yang sudah ditentukan menurut UU Perkawinan. Pengaturan tentang poligami di hukum positif seakan mempersulit suami untuk poligami, sedangkan hukum islam sendiri tidak terlalu mempersulit seorang suami untuk poligami. Oleh karena itu, fokus dipenelitian ini hanya dimaksudkan agar kedua hukum yakni hukum islam dan hukum positif, dalam peraturan poligaminya, dapat berjalan secara sinkron sehingga tidak menimbulkan permasalahan. ${ }^{8}$

Berdasarkan penelitian terdahulu, bahwa aturan mengenai persetujuan isteri yang merupakan syarat mutlak dalam pengajuan permohonan poligami. Hal ini merupakan salah satu bentuk perlindungan negara terhadap hak isteri. Persetujuan isteri bisa tidak diperlukan manakala ditemukan kondisi sebagai berikut: Isteri/isteri-isterinya tidak mungkin diminta persetujuannya dan tidak dapat menjadi pihak dalam perjanjian, atau apabila tidak ada kabar dari isterinya selama sekurang-kurangnya 2 (dua) tahun, atau karena sebab-sebab lainnya yang perlu mendapat penilaian dari hakim pengadilan. (Pasal 5 ayat 2 UU Perkawinan). Tujuan penelitian ini ingin mengetahui bagaimana konsekuensi hukum bagi suami yang melaksanakan poligami yang melanggar aturan hukum positif Indonesia dan Hukum Islam. Aturan hukum perkawinan mencakup UU Perkawinan, Peraturan Pemerintah Nomor 9 Tahun 1975 Tentang Peraturan Pelaksana dari UU Perkawinan, dan Instruksi Presiden Nomor 1 Tahun 1991 Tentang Kompilasi Hukum Islam. Kemudian dari beberapa aturan tersebut disinggung pula dengan aturan hukum pidana yakni KUHP sehingga kemudian dapat ditarik konsekuensi hukum bagi suami yang melaksanakan poligami yang melanggar aturan kedua hukum tersebut.

\section{B. PERMASALAHAN}

Berdasarkan latar belakang yang sudah diuraikan dalam artikel ini, maka dapat ditarik permasalahan yakni: Bagaimanakah konsekuensi hukum bagi suami yang melaksanakan poligami yang melanggar aturan hukum positif Indonesia dan hukum Islam?

\section{METODE PENELITIAN}

Penelitian ini merupakan penelitian hukum normatif. Penelitian ini menggunakan pendekatan perundang-undangan dan pendekatan perbandingan. Spesifikasi penelitian ini menggunakan deskriptif analitis, yaitu suatu penelitian yang menggambarkan secara menyeluruh dan sistematis obyek dari pokok permasalahan. ${ }^{9}$ Artikel ini menganalisis serta menyusun data yang telah terkumpul, untuk dapat diambil kesimpulannya serta

\footnotetext{
${ }^{8}$ Reza Fitra Ardhian, Satrio Anugrah, and Bima Setyawan, "Poligami Dalam Hukum Islam Dan Hukum Positif Indonesia Serta Urgensi Pemberian Izin Poligam Di Pengadilan Agama," Privat Law 3, no. 2 (2015): 100-107, file:///C:/Users/Klinikcomp/Downloads/Documents/164461-ID-poligami-dalam-hukum-islam-dan-hukum-pos.pdf.

${ }^{9}$ Alimuddin, Aplikasi Pembaharuan Hukum Dalam Teori Socio Legal Studies, DitJen Badan Peradilan, 2014, www.badilag.net.
} 
memberikan suatu kajian mengenai konsekuensi hukum bagi suami yang melaksanakan poligami yang melanggar aturan hukum positif Indonesia dan hukum Islam. Data yang ingin diperoleh dalam penelitian ini dikumpulkan dengan cara studi dokumen/kepustakaan. Metode ini digunakan untuk mengumpulkan data sekunder. Menurut Syamsudin, ${ }^{10}$ studi dokumen atau kepustakaan adalah kegiatan mengumpulkan dan memeriksa atau menelusuri dokumen-dokumen atau kepustakaan yang dapat memberikan informasi atau keterangan yang dibutuhkan dalam penelitian ini. Data yang diperoleh dalam penelitian ini disusun secara logis dan sistematis, selanjutnya dianalisis dengan mempergunakan metode analisis kualitatif, dan kemudian disajikan secara kualitatif.

\section{HASIL DAN PEMBAHASAN}

Perkawinan poligami merupakan perbuatan hukum yang tidak dilarang oleh ketentuan agama, namun hanya diatur sedemikan rupa agar penerapannya benar-benar dilakukan sesuai dengan tujuan yang dibenarkan oleh hukum positif maupun hukum Islam. ${ }^{11}$ Hukum positif adalah hukum yang berlaku saat ini. Bagir Manan mengartikan hukum positif yang berlaku di Indonesia bahwa "Hukum positif adalah kumpulan asas dan kaidah hukum tertulis dan tidak tertulis yang pada saat ini sedang berlaku dan mengikat secara umum atau khusus dan ditegakkan oleh atau melalui pemerintah atau pengadilan dalam negara Indonesia". ${ }^{2}$

Oleh karena itu, agar perkawinan poligami dapat dilakukan dengan benar sesuai tujuan perkawinan, maka perlu diatur dalam suatu peraturan perundang-undangan sebagai ketentuan pelaksana dari syariat perkawinan. Artinya negara wajib mengatur segala perbuatan hukum demi terciptanya ketertiban hukum dan memberikan jaminan hukum bagi warganya, termasuk masalah perkawinan.

Hal ini dibuktikan dengan beberapa hukum positif yang mengatur mengenai pemberian izin poligami seperti Undang-Undang Nomor 1 Tahun 1974 sebagaimana telah diubah dengan Undang-Undang Nomor 16 Tahun 2019 Tentang Perkawinan, Peraturan Pemerintah Nomor 9 Tahun 1975 Tentang Peraturan Pelaksana dari UndangUndang Nomor 1 Tahun 1974, dan Instruksi Presiden Nomor 1 Tahun 1991 Tentang Kompilasi Hukum Islam. Tentunya dalam penerapan peraturan ini dapat memperoleh akibat hukum atau konsekuensi hukum apabila ada pelanggaran.

Didalam Pasal 49 Undang-Undang Nomor 7 Tahun 1989 yang telah diubah dengan Undang-Undang Nomor 3 Tahun 2006 dan perubahan kedua dengan Undang-Undang Nomor 50 tahun 2009 Tentang Peradilan Agama menyatakan bahwa "Pengadilan agama bertugas dan berwenang memeriksa, memutus, dan menyelesaikan perkara di tingkat pertama antara orang-orang yang beragama Islam dibidang: perkawinan, waris, wasiat, hibah, wakaf, zakat, infaq, shadaqah, dan ekonomi syari'ah".

Ketentuan meskipun seorang suami yang akan melangsungkan perkawinan poligami merasa mampu berlaku adil terhadap istri-istrinya, tidak hanya sebatas ucapan

\footnotetext{
${ }^{10}$ Alimuddin.

${ }^{11}$ Azni, "Izin Poligami Di Pengadilan Agama (Suatu Tinjauan Filosofis)."

${ }^{12}$ Bagir Manan, Hukum Positif Indonesia: Satu Kajian Teoritik (Yogyakarta, Indonesia: FH UII Press, 2004).
} 
atau pengakuan semata, seorang suami yang akan melangsungkan perkawinan poligami haruslah menempuh prosedur sesuai ketentuan hukum yang berlaku. Seorang suami yang bermaksud untuk beristri lebih dari seorang maka wajib mengajukan permohonan secara tertulis kepada pengadilan. Pasal 40 PP Nomor 9 Tahun 1975 dan Pasal 41 PP Nomor 9 Tahun 1975 menegaskan bahwa pengadilan kemudian memeriksa mengenai :

a. Ada atau tidaknya alasan yang memungkinkan seorang suami kawin lagi seperti : istri tidak dapat menjalankan kewajibannya sebagai istri, istri mendapat cacat badan atau penyakit yang tidak dapat disembuhkan atau istri tidak dapat melahirkan keturunan;

b. Ada atau tidaknya persetujuan dari istri, baik persetujuan lisan maupun tertulis, apabila persetujuan itu merupakan lisan, persetujuan itu harus diucapkan di depan sidang pengadilan;

c. Ada atau tidak adanya kemampuan suami untuk menjamin keperluan hidup istri-istri dan anak-anak, dengan memperlihatkan: surat keterangan mengenai penghasilan suami yang ditanda-tangani oleh badan tempat bekerja; atau surat keterangan pajak penghasilan; atau surat keterangan lain yang dapat diterima oleh Pengadilan;

d. Ada atau tidaknya jaminan bahwa suami akan berlaku adil terhadap istri-istri dan anakanak mereka dengan pernyataan atau janji dari suami yang dibuat dalam bentuk yang ditetapkan untuk itu.

Apabila prosedur sebagaimana yang telah diuraikan diatas tidak dipenuhi dalam melangsungkan perkawinan poligami, maka berlakulah sanksi pidana terhadap pihak pihak yang melangsungkan perkawinan poligami tanpa adanya persetujuan dari istri yang sah sebelumnya. Hal tersebut tentunya harus dibuktikan dengan nyata bahwa benar telah dilangsungkannya perkawinan poligami tanpa adanya persetujuan istri. Apabila secara nyata benar telah diketahui bahwa seorang suami telah melangsungkan perkawinan untuk yang kedua kalinya tanpa adanya persetujuan istri yang dapat dibuktikan baik berupa bukti petujuk, keterangan saksi dan lain sebagainya, maka berlakulah penerapan sanksi terhadapnya sesuai dengan ketentuan yang berlaku. ${ }^{13}$

Perbuatan poligami diperbolehkan apabila telah memenuhi persyaratan sebagaimana disebutkan di dalam Pasal 3 ayat (2), Pasal 4 dan Pasal 5 UU Perkawinan. Pasal 3 Ayat (2) UU Perkawinan berbunyi: "Pengadilan dapat memberi izin kepada seorang suami untuk beristeri lebih dari seorang apabila dikehendaki oleh pihak yang bersangkutan". Pasal 4 UU Perkawinan berbunyi: “(1) Dalam hal seorang suami akan beristeri lebih dari seorang sebagaimana tersebut dalam Pasal 3 ayat (2) Undang-undang ini maka ia wajib mengajukan permohonan kepada pengadilan di daerah tempat tinggalnya. (2) Pengadilan dimaksud dalam ayat (1) pasal ini hanya memberi izin kepada seorang suami yang akan beristeri lebih dari seorang apabila: a. isteri tidak dapat menjalankan kewajibannya sebagai isteri; b. isteri mendapat cacat badan atau penyakit yang tidak dapat disembuhkan; c. isteri tidak dapat melahirkan keturunan".

Sedangkan Pasal 5 UU Perkawinan berbunyi: “(1) Untuk dapat mengajukan permohonan kepada pengadilan sebagaimana dimaksud dalam Pasal 4 ayat (1) Undang-

${ }^{13}$ Muhammad Yusuf Siregar, "Sanksi Pidana Terhadap Perkawinan Poligami Tanpa Adanya Persetujuan Istri," Jurnal Ilmiah Advokasi 5, no. 01 (2017). 
undang harus dipenuhi syarat syarat sebagai berikut a. Ada persetujuan dari isteri/isteriisteri; b. adanya kepastian bahwa suami mampu menjamin keperluan hidup isteri-isteri dan anak-anak mereka; c. Adanya jaminan bahwa suami akan berlaku adil terhadap istriisteri dan anak-anak mereka. (2) Persetujuan yang dimaksud pada ayat (1) huruf a pasal ini tidak diperlukan bagi seorang suami apabila isteri/isteri-isterinya tidak mungkin diminta persetujuannya dan tidak dapat menjadi pihak dalam perjanjian, atau apabila tidak ada kabar dari isterinya selama sekurang-kurangnya 2 (dua) tahun, atau karena sebab-sebab lainnya yang perlu mendapat penilaian dari hakim pengadilan".

Apabila ketentuan tersebut dilanggar maka pelaku poligami illegal (yang tidak mendapatkan perizinan) yang dalam hal ini adalah suami, dapat diancam dikenakan konsekuensi atau sanksi pidana kategori pelanggaran sebagaimana diatur Pasal 45 Peraturan Pemerintah Nomor 9 Tahun 1975. ${ }^{14}$

Hukum pidana menentukan sanksi terhadap setiap pelanggaran hukum yang dilakukan. Sanksi itu pada prinsipnya merupakan penambahan penderitaan dengan sengaja. Penambahan penderitaan dengan sengaja ini pula yang menjadi pembeda terpenting antara hukum pidana dengan hukum yang lainnya. ${ }^{15}$

Istilah "pidana" merupakan istilah yang lebih khusus, yaitu menunjukkan sanksi dalam hukum pidana. Pidana adalah sebuah konsep dalam bidang hukum pidana yang masih perlu penjelasan lebih lanjut untuk dapat memahami arti dan hakekatnya. ${ }^{16}$

Muladi dan Barda Nawawi berpendapat bahwa unsur pengertian pidana, meliputi:

a. pidana itu pada hakekatnya merupakan suatu pengenaan penderitaan atau nestapa atau akibat-akibat lain yang tidak menyenangkan;

b. pidana itu diberikan dengan sengaja oleh orang atau badan yang mempunyai kekuasaan (oleh yang berwenang);

c. pidana itu dikenakan pada seseorang yang telah melakukan tindak pidana menurut undangundang.

Apabila dilihat dari filosofinya, hukuman mempunyai arti yang sangat beragam. $\mathrm{R}$. Soesilo menggunakan istilah "hukuman" untuk menyebut istilah "pidana" dan ia merumuskan bahwa apa yang dimaksud dengan hukuman adalah suatu perasaan tidak enak (sangsara) yang dijatuhkan oleh hakim dengan vonis kepada orang yang telah melanggar undang-undang hukum pidana. ${ }^{17}$

Satochid Kartanegara berpendapat bahwa "hukuman (pidana) itu bersifat siksaan atau penderitaan, yang oleh undang-undang hukum pidana diberikan kepada seseorang yang melanggar sesuatu norma yang ditentukan oleh undang-undang hukum pidana, dan siksaan atau penderitaan itu dengan keputusan hakim dijatuhkan terhadap diri orang yang dipersalahkan itu. Sifat yang berupa siksaan atau penderitaan itu harus diberikan kepada hukuman (pidana), karena pelanggaran yang dilakukan oleh seseorang terhadap norma yang ditentukan oleh undangundang hukum pidana itu merupakan pelanggaran atau

\footnotetext{
${ }^{14}$ Raflisman, "Sanksi Hukum Poligami Tanpa Izin Pengadilan Agama Dalam Kitab Undang-Undang Hukum Pidana Ditinjau Dari Hukum Islam,” QIYAS Vol. 1, No. 1, April 2016 1, no. 1 (2016).

${ }^{15}$ Siregar, "Sanksi Pidana Terhadap Perkawinan Poligami Tanpa Adanya Persetujuan Istri."

${ }^{16}$ Siregar.

${ }^{17}$ Siregar.
} 
perkosaan kepentingan hukum yang justru akan dilindungi oleh undang-undang hokum pidana". Secara garis besar, tujuan pidana menurut teori relatif bukanlah sekedar pembalasan, akan tetapi untuk mewujudkan ketertiban di dalam masyarakat. ${ }^{18}$

Sebagaimana dikemukakan Koeswadji dalam bukunya Perkembangan Macammacam Pidana Dalam Rangka Pembangunan Hukum Pidana mengemukakan bahwa tujuan pokok dari pemidanaan yaitu :

1. Untuk mempertahankan ketertiban masyarakat (dehandhaving van demaatschappelijke orde);

2. Untuk memperbaiki kerugian yang diderita oleh masyarakat sebagai akibat dari terjadinya kejahatan. (het herstel van het doer de misdaad onstane maatschappelijke nadeel);

3. Untuk memperbaiki si penjahat (verbetering vande dader);

4. Untuk membinasakan si penjahat (onschadelijk maken van de misdadiger);

5. Untuk mencegah kejahatan (tervoorkonning van de misdaad).

Romli Atmasasmita dalam bukunya Kapita Selekta Hukum Pidana dan Kriminologi menyatakan bahwa Penjatuhan pidana kepada pelaku kejahatan mempunyai sandaran pembenaran yaitu:

1. Dijatuhkannya pidana akan memuaskan perasaan balas dendam si korban, baik perasaan adil bagi dirinya, temannya maupun keluarganya. Perasaan ini tidak dapat dihindari dan tidak dapat dijadikan alasan untuk menuduh tidak menghargai hukum.

2. Penjatuhan pidana dimaksdkan sebagai peringatan kepada pelaku kejahatan dan anggota masyarakat yang lainnya, bahwa setiap perbuatan yang merugikan orang lain atau memperoleh keuntungan dari orang lain secara tidak wajar maka akan menerima ganjarannya.

3. Pidana dimaksudkan untuk menunjukkan adanya kesebandingan antara beratnya suatu pelanggaran dengan pidana yang dijatuhkan.

Muladi juga berpendapat bahwa pidana (punisment) selalu mengundang unsurunsur sebagai berikut:

a. Pada hakekatnya merupakan suatu pengertian penderitaan atau nestapa atau akibatakibat lain yang tidak menyenangkan.

b. Diberikan dengan sengaja oleh orang atau badan yang mempunyai kekuatan (oleh yang berwenang).

c. Dikenakan kepada seseorang yang telah melakukan tindak pidana menurut undangundang.

Jika disimak keberadaan Pasal 55 ayat (1) KUHP, maka ada keharusan untuk menemukan peran pelaku dan para pelaku dimintai pertanggungjawabannya sesuai dengan peranannya masing-masing. Artinya dalam prinsip deelneming tidaklah bisa semua pelaku adalah sama-sama sebagai orang yang melakukan, atau sama-sama sebagai orang yang menyuruh lakukan, apalagi sama-sama sebagai turut serta melakukan. Dalam konteks ini, suatu peristiwa pidana yang pelakunya lebih dari satu orang meminta adanya

${ }^{18}$ Siregar. 
penemuan dari penegak hukum untuk menemukan kedudukan dan peran dari masingmasing pelaku. ${ }^{19}$

Dalam suatu peristiwa pidana adalah sangat penting menemukan hubungan antar pelaku dalam menyelesaikan suatu tindak pidana, yakni bersama-sama melakukan tindak pidana; Seorang mempunyai kehendak dan merencanakan kejahatan sedangkan ia menggunakan orang lain untuk melaksanakan tindak pidana tersebut. Seorang saja yang melakukan suatu tindak pidana, sementara orang lain membantu melaksanakan tidak pidana tersebut.

Secara garis besar bisa dikelompokan, penyertaan bisa berdiri sendiri, mereka yang melakukan dan turut serta melakukan. Tanggung jawab pelaku dinilai sendiri-sendiri atas perbuatan yang dilakukan. Penyertaan bisa juga dalam arti tidak berdiri sendiri, pembujuk, pembantu dan yang menyuruh untuk melakukan suatu tindak pidana.

Bila diperhatikan rumusan Pasal 55 tersebut, maka tidak mungkin dalam pembuktian Pasal 55 KUHP dalam pemeriksaan perkara pidana, pasal ini dinyatakan sebagai terbukti hanya dengan menyimpulkan adanya kerjasama kolektif tanpa menunjukkan peran dari masing-masing pelaku dari suatu tindak pidana. Apalagi di antara pelaku terdapat hubungan kerja atasan dan bawahan dan disisi lain ada kewenangan-kewenangan dari hubungan atasan-bawahan dimaksud.

Dengan hanya menyebutkan adanya kerjasama secara kolektif, maka tidak jelas kapasitas dan tanggung jawab atas perbuatan yang mana yang harus dipertanggung jawabkan seorang pelaku tindak pidana (terdakwa) apakah dalam posisinya sebagai yang melakukan, atau sebagai yang menyuruh lakukan atau sebagai turut serta melakukan. Artinya pembuktian Pasal 55 ayat (1) ke-1 KUHP tidak cukup dengan sebatas mendalilkan adanya hubungan yang saling melengkapi (kolektif). Meskipun disisi lain terhadap soal ini ada pendapat yang berbeda, tetapi tentu jika dikaitkan dengan Pasal 55 KUHP adanya kerjasama secara kolektif adalah baru langkah permulaan bagi menentukan peran dan tanggung jawab pelaku tindak pidana. Karena belum bisa dijadikan sebagai dasar bagi hakim untuk menyatakan Pasal 55 KUHP sebagai telah terbukti.

Seorang pelaku poligami dapat dikenakan sanksi dengan kesalahan yang dibuatnya tergantung pasal berapa yang akan dikenakan oleh hakim. Hal tersebut tergantung dari sudut pandang hakim dalam menjatuhkan pidana kepada pelaku poligami illegal. Setelah pelaku dikenakan sanksi barulah orang yang menikahkan (penghulu) dapat dikenakan sanksi hukum sebagimana termaktub di dalam Pasal 55 KUHP penyertaan melakukan perbuatan tindak pidana.

Ketentuan sanksi pidana yang diatur didalam Pasal 45 Peraturan Pemerintah Nomor 9 Tahun 1975 merupakan peristiwa pidana yang digolongkan kepada jenis pidana pelanggaran (contraventions) bukan peristiwa pidana yang digolongkan kepada kejahatan ringan (rechtsdeliktern). Ancaman sanksi bagi pelaku yang melanggar ketentuan Pasal 3, 10 ayat (3) dan Pasal 40 Peraturan Pemerintah No 9 tahun 1975 inipun tergolong ringan

${ }^{19}$ Raflisman, "Sanksi Hukum Poligami Tanpa Izin Pengadilan Agama Dalam Kitab Undang-Undang Hukum Pidana Ditinjau Dari Hukum Islam.” 
yaitu hanya sanksi dengan ancaman denda setinggi-tinggi Rp. 7.500.- (tujuh ribu lima ratus rupiah)..$^{20}$

UU Perkawinan juga mengatur mengenai hal-hal yang menjadi penghalang bagi seorang suami yang ingin berpoligami yang terdapat dalam Pasal 9, 15 dan, 24 yaitu sebagai berikut:

1. Pasal 9 UU Perkawinan yang berbunyi "Seseorang yang masih terikat tali perkawinan dengan orang lain tidak dapat kawin lagi kecuali hal yang tersebut pada Pasal 3 Ayat (2) dan Pasal 4 undang-undang ini";

2. Pasal 15 UU Perkawinan yang berbunyi "Barangsiapa karena perkawinan dirinya masih terikat dengan salah satu dari kedua belah pihak dan atas dasar masih adanya perkawinan, dapat mencegah perkawinan yang baru, dengan tidak mengurangi ketentuan Pasal 3 ayat (2) dan Pasal 4 Undang-undang ini";

3. Pasal 24 UU Perkawinan yang berbunyi "Barangsiapa karena perkawinan masih terikat dirinya dengan salah satu pihak dan atas dasar masih adanya perkawinan dapat mengajukan pembatalan perkawinan".

4. Selanjutnya Pasal 45 Peraturan Pemerintah Nomor 9 Tahun 1975 Tentang Peraturan Pelaksana dari Undang-Undang Nomor 1 Tahun 1974 menyebutkan bahwa "Barangsiapa yang melanggar ketentuan yang diatur dalam Pasal 3, Pasal 10 ayat (3), Pasal 40 Peraturan Pemerintah ini dihukum dengan hukuman denda setinggi-tingginya Rp.7.500,- (tujuh ribu lima ratus rupiah)". Ketentuan Pasal 40 yang dimaksud pada Pasal 45 Peraturan Pemerintah Nomor 9 Tahun 1975 adalah "Apabila seorang suami bermaksud untuk beristeri lebih dari seorang maka ia wajib mengajukan permohonan secara tertulis kepada Pengadilan”. Ketentuan Pasal 45 atas pelanggaran terhadap Pasal 40 dimaksud berkaitan dengan ketiadaan izin poligami dari pengadilan, sehingga perbuatan poligami yang dilakukan secara liar (tanpa izin pengadilan) dapat dikenakan sanksi pidana berupa membayar denda setinggi- tingginya Rp.7.500,- (tujuh ribu lima ratus rupiah).

Dari unsur-unsur pasal di maksud dapatlah diketahui bahwa larangan terhadap poligami bukan terletak kepada hukum pernikahannya, tapi terletak kepada syarat administrasi yang harus terpenuhi terlebih dahulu yang dibuktikan dengan adanya penetapan dari pengadilan. Unsur-unsur yang terdapat didalam Pasal 45 Peraturan Pemerintah Nomor 9 Tahun 1975 tidak jauh berbeda dengan rumusan pasal yang terdapat draft RUU Hukum Materil Pengadilan Agama (selanjutnya disebut RUU HMPA). Ketentuan Pasal 145 Draft RUU HMPA menyebutkan bahwa "Setiap orang yang melangsungkan perkawinan dengan isteri kedua, ketiga atau keempat tanpa mendapat izin terlebih dahulu dari pengadilan sebagaimana dimaksud dalam Pasal 52 ayat (1) dipidana dengan pidana denda paling banyak Rp. 6.000.000,- (enam juta rupiah) atau hukuman kurungan paling lama 6 (enam) bulan".

Berdasarkan redaksi Pasal 145 draft RUU HMPA dapatlah diketahui bahwa perbuatan poligami sama sekali tidak dilarang selama suami yang ingin berpoligami

${ }^{20}$ Raflisman. 
mendapatkan izin dari pengadilan. Perbuatan poligami yang dilakukan secara illegal (tanpa izin pengadilan) dapat dikenakan sanksi pidana berupa delik pidana pelanggaran dengan sanksi yang sedikit lebih tinggi dari ketentuan Pasal 45 Peraturan Pemerintah Nomor 9 Tahun 1975 yaitu membayar denda paling banyak Rp. 6.000.000,- (enam juta rupiah) atau hukuman kurungan paling lama 6 (enam) bulan..$^{21}$

Berbeda halnya dengan ketentuan sanksi pidana atas perbuatan yang diatur di dalam Pasal 279 KUHP. Dalam pasal 279 KHUP berbunyi sebagai berikut :

1. Di ancam dengan pidana penjara paling lama lima tahun.

a. Barang siapa mengadakan perkawinan padahal mengatahui bahwa perkawinan atau perkawinan-perkawinan yang telah ada menjadi penghalang yang sah untuk itu.

b. Barang siapa mengadakan perkawinan padahal mengetahui bahwa perkawinan atau perkawinan-perkawinan pihak lain menjadi penghalang untuk ini.

2. Jika yang melakukan perbuatan berdasarkan ayat 2 butir 1 menyebutkan kepada pihak lain bahwa perkawinan yang telah ada menjadi pengahalang yang sah untuk itu diancam dengan pidana penjara paling lama tujuh tahun.

Ketentuan pasal tersebut memandang perbuatan poligami sebagai perbuatan pidana kategori kejahatan ringan. Unsur-unsur yang terdapat didalam Pasal 279 ayat (1) KUHP yaitu:

1. Unsur subjektif, yaitu "Barang siapa". Barang siapa ini menyebutkan orang sebagai subjek hukum yang dapat dimintai pertanggungjawaban didepan hukum.

2. Unsur objektif, yaitu:

a. Mengadakan perkawinan. Unsur ini menyebutkan seorang suami yang menikah lagi dengan wanita lain yang perkawinannya dipandang sah menurut hukum masingmasing agama dan kepercayaannya itu

b. Mengetahui perkawinan-perkawinannya yang ada. Unsur ini menyebutkan seorang suami yang melakukan perbuatan sebagaimana disebut pada huruf (a), tapi ia secara sadar mengetahui bahwa ia sedang dalam ikatan perkawinan.

c. Mengetahui perkawinan-perkawinan pihak lain. Unsur ini menyebutkan calon mempelai pasangannya mengetahui bahwa calon pasangannya masih dalam ikatan perkawinan yang sah.

d. Adanya penghalang yang sah. Unsur ini menyebutkan bahwa kedua calon mempelai memang sudah mengetahui bahwa perkawinan yang akan mereka langsungkan memiliki halangan yang sah, karena calon suaminya dalam ikatan perkawinan yang sah.

Berdasarkan unsur-unsur yang terkandung didalam Pasal 279 KUHP, maka dapat diketahui bahwa Pasal 279 KUHP bukan untuk mengancam atau melarang seorang suami untuk berpoligami, namun pasal ini hanya mengancam perbuatan poligami yang dilakukan secara illegal.

Selanjutnya perbedaan sanksi pidana yang memandang perbuatan poligami illegal sebagaimana diatur dalam Pasal 45 Peraturan Pemerintah Nomor 9 Tahun 1975 dengan

\footnotetext{
${ }^{21}$ Raflisman.
} 
Pasal 279 KUHP adalah perbedaan norma-norma dalam ikatan perkawinan yang diadopsi kedalam hukum positif. Pasal 45 Peraturan Pemerintah Nomor 9 Tahun 1975 memandang perbuatan poligami illegal hanya sebagai perbuatan pelanggaran administratif saja, dikarenakan hukum dasar perkawinan membolehkan poligami jika rukun dan syarat nikah sudah terpenuhi.

Sementara itu Undang-Undang Perkawinan memandang perkawinan sebagai perbuatan untuk melaksanakan ibadah, sedangkan pencatatan perkawinan hanyalah bersifat administratif. Ketentuan poligami dipandang sah selama ketentuan agama dan kepercayaannya itu terpenuhi dan apabila perbuatan poligami tersebut dilaksanakan tanpa adanya penetapan izin dari pengadilan, maka sanksi yang diberikan kepada pelaku poligami yang melanggar ketentuan tersebut dikenakan sanksi dikategorikan pelanggaran.

Akan berbeda jika melihat pelanggaran poligami dari sudut pandang Pasal 279 KUHP. Perbedaan tersebut disebabkan Pasal 279 KUHP memandang perkawinan bukan sebagai pelaksanaan ibadah, melainkan sebagai suatu hubungan perdata.

Beberapa putusan yang ditetapkan terhadap kasus poligami, hukumannya relatif ringan dibandingkan kerugian yang ditimbulkan oleh perbuatan tersebut, kerugian tersebut bukan hanya di alami oleh istri secara batin saja tetapi juga secara materi, namun hal ini juga berakibat buruk terhadap perkembangan anak.

Ketika seorang pria melakukan perkawinan poligami di luar prosedur yang telah ditetapkan dalam Undang-Undang Nomor 1 Tahun 1974, maka perbuatan tersebut merupakan suatu perbuatan pidana yang bertentangan dengan Pasal 279 KUHP sehingga pelaku perbuatan tersebut harus dipertanggungjawabakan secara pidana. Pelaku tindak pidana poligami seperti yang dinyatakan dalam Pasal 279 KUHP dijatuhi pidana. Pidana (hukuman) yang dijatuhi tersebut berbeda-beda hal ini dilihatberdasarkan cara perbuatan itu dilakukan.

Dapat dijelaskan bahwa bila suami tahu bahwa dia sudah dalam ikatan perkawinan namun tetap menikah dengan orang lain tanpa izin istri, maka pasal ini bisa ditetapkan. Hal ini juga dipertegas dalam Surat Edaran Mahkamah Agung No.4 Tahun 2016 Tentang Pemberlakuan Rumusan Hasil Pleno Kamar Mahkamah Agung 2016 sebagai pedoman pelaksanaan tugas pengadilan yang menyatan bahwa : "bahwa perkawinan yang dilakukan oleh seorang suami dengan perempuan lain sedangkan suami tersebut tidak mendapkan izin isteri untuk melangsungkan perkawinan lagi, maka Pasal 279 KHUP dapat di terapkan".

Ini membuktikan bahwa tindakan dalam perkawinan poligami yang dapat dikategorikan sebagai tindak pidana sering terjadi, namun jarang sekali terkuak di permukaan. Selain itu pula perbuatan tersebut sulit sekali disentuh oleh hukum pidana, hal ini tak lepas dari berbagai macam faktor yang melatar belakanginya baik dikarenakan sanksi hukum yang lemah dan tidak memihak kepada korban, maupun sanksi hukum yang tidak tegas, dan tidak jelas sehingga tidak bisa memberikan efek jera bagi masyarakat, 
serta pengawasan yang masih sangat minim dari pemerintah dan aparatur penegak hukum.

Faktor lain yang mendukung maraknya pelanggaran perkawinan poligami yaitu rendahnya kesadaran dan pemahaman dari masyarakat tentang hukum, ambiguitas dari undang-undang tentang perkawinan yang menyebabkan mudahnya para pelaku untuk berdalih atas perbuatan yang dilakukannya.

Dari data tesebut dapat disimpulkan bahwa pelaku poligami maupun pelaksana yang membantu terealisasinya perkawinan poligami yang tidak sesuai dari undangundang adalah suatu tindak pidana yang dapat diancam sanksi pidana. Maka dari itu harus adanya penegakan hukum yang maksimal guna memberikan perlindungan dan jaminan hukum bagi masyarakat.

Akibat dari suami melanggar perjanjian perkawinan poligami dalam hal tidak memberikan nafkah kepada isteri dan anak mereka serta tidak dapat berbuat adil, maka dalam UU Perkawinan Pasal 1 menegaskan bahwa suami wajib melindungi isteri dan memberikan segala sesuatu keperluan hidup berumah tangga sesuai dengan kemampuannya. Sedangkan dalam Kompilasi Hukum Islam (KHI) Pasal 80 ayat 4 menjelaskan bahwa suami dengan penghasilannya menaggung : nafkah, kiswah termpat kediaman bagi isteri, biaya rumah tangga, dan pendidikan anak.

Dari aturan tersebut isteri dapat menuntut suami apabila melanggar perjanjian dan tidak berbuat adil dari perkawinan poligami yaitu dengan mengganti pembiayaan nafkah yang tidak diberikan selama perkawinan. Suatu hukum yang menyangkut tentang kewajiban pasti terdapat implikasi bagi hukum yang dilanggar. Hakim dapat menentukan pembayaran nafkah tersebut. apabila keputusan-keputusan majlis hakim tidak di penuhi oleh tergugat, maka panitera dan juru sita pengadilan agama dapat mengeksekusi dengan cara menyita harta tergugat setelah keputusan tersebut mempunyai kekuatan hukum.

Hukum positif telah menyinggung bahwasannya dalam hal suami hendak meminta izin poligami harus mendapatkan persetujuan oleh istri dan pengadilan. Di sini negara memiliki andil dalam melindungi hak isri untuk memberikan izin poligami. Perkawinan itu dianggap tidak sah apabila suami dalam berpoligami melanggar aturan hukum positif, sehingga dikhawatirkan di kemudian hari pernikahan poligami tersebut tidak memiliki kekuatan hukum. Konsekuensi ini dipahami dari hubungan kalimat 'wajib' pada Pasal 4 ayat (1) UU Perkawinan dan Pasal 56 ayat (3) Kompilasi Hukum Islam yang menyatakan “tidak mempunyai kekuatan hukum".

Izin untuk berpoligami menurut ketentuan di atas adalah wajib, sehingga apabila dilakukan tidak lebih dahulu mendapat izin, maka perkawinan itu tidak mempunyai kekuatan hukum. Dengan demikian perkawinan itu juga tidak sah karena dianggap tidak pernah telah terjadi.

Hal ini sesuai dengan kedudukan urgensi izin pengadilan dalam perkawinan poligami menurut hukum Islam, dimana hukum formal itu mengikuti hukum materil yang turut menentukan sahnya perkawinan. Perkawinan yang hanya memenuhi ketentuan 
materil tetapi tidak memenuhi ketentuan formalnya, dianggap perkawinan itu tidak pernah terjadi, yang dalam istilah fiqh disebut Wujuduhu ka adamihi, sedangkan perkawinan yang telah memenuhi ketentuan hukum formal, tetapi ternyata tidak memenuhi ketentuan hukum materiil, maka perkawinan itu dapat dibatalkan. Oleh karena itu, meskipun secara materil perkawinan itu sah tetapi secara formal belum sah, sehingga oleh negara selamanya perkawinan itu dianggap tidak pernah ada kecuali jika dapat dibuktikan dengan akta nikah yang dikeluarkan oleh Pegawai Pencatat Nikah (PPN). ${ }^{22}$

Konsekuensi perkawinan tersebut selanjutnya akan menjadi lebih rumit, karena segala akibat hukum dari hubungan perkawinan itu juga dianggap tidak ada, seperti anakanak yang lahir dari perkawinan tersebut, sesuai dengan Pasal 42 dan 43 UU Perkawinan dianggap anak lahir diluar perkawinan sehingga tidak mempunyai hubungan perdata (hukum) kecuali dengan ibunya. Maka dari itu, semua hak-hak perdata anak dari perkawinan tersebut akan terlepas dari ayahnya, artinya ayahnya tidak mempunyai kewajiban apapun secara hukum, dan dalam hal ini baik ibu atau anak-anak itu sendiri tidak dapat menuntut hak-hak mereka, termasuk hak-hak yang menyangkut harta kekayaan.

Dalam hukum positif ada beberapa syarat poligami di antaranya adanya persetujuan dari isteri. Syarat ini justru dapat menyulitkan suami yang ingin melakukan poligami padahal dalam hukum Islam yang telah dijabarkan dalam kitab fikih terutama fikih Syafi 'iyyah tidak diketemukan syarat persetujuan isteri tersebut. ${ }^{23}$

Bukti nyata bahwa kitab yang dipedomani dalam merumuskan UU Perkawinan adalah termasuk kitab-kitab madzhab Syafi' '̌yyah, sedangkan kandungan isi kitab yang disebutkan di bawah ini tentang persoalan persetujuan isteri untuk berpoligami tidak ditemukan. Kitab yang digunakan sebagai pedoman oleh pakar hukum Islam dan ulama dalam merumuskan Undang-Undang Nomor 1 Tahun 1974 Tentang Perkawinan antaranya adalah; Hāsyyah al-Bājury, Fath al-Mu'in, Syarqawy 'Ala al-Tahrīr, Qawānīn Syar'`yyah Li al- Sayyid Bin Yahya, Bughyah al-Mustarsyidin, Qalyuby wa Umayrah, Fath al- Wahab, Tuhfah dan al-Fiqh' 'alā- Madzāhib al-Arba'ah. Kitab-kitab di atas yang dijadikan pedoman dan rujukan dalam penyusunan UU Perkawinan adalah kitab-kitab fikih Syafi'`yyah yang tidak pernah mensyaratkan adanya persetujuan isteri untuk berpoligami. $^{24}$

Hukum poligami menurut para ulama dan ahli fikih Syafi'iyyah adalah boleh, dengan syarat tidak melebihi dari empat orang, jika melebihi dari empat orang, maka hukumnya haram. Adapun poligami yang dimaksud adalah perkawinan yang dilaksanakan melebihi dari satu orang dalam waktu yang sama dan tidak lebih pula dari empat orang isteri. Berdasarkan beberapa pendapat ulama dapat dipahami bahwa poligami dibolehkan dalam agama, dengan syarat bisa berlaku adil terhadap semua isteri baik lahiriah maupun batiniah. Selain itu juga berbuat adil untuk anak-anaknya dalam

\footnotetext{
${ }^{22}$ Azni, "Izin Poligami Di Pengadilan Agama (Suatu Tinjauan Filosofis)."

${ }^{23}$ Riyandi S, "Syarat Adanya Persetujuan Isteri Untuk Berpoligami (Analisis Ushul Fikih Syafi 'İyyah Terhadap Undang-Undang Perkawinan Nomor 1 Tahun 1974)," Ilmiah, Jurnal Futura, Islam 15, no. 1 (2015): 111-42. ${ }^{24} \mathrm{~S}$.
} 
segala kebutuhan rumah tangga. Intinya para ulama sependapat dalam masalah poligami, hanya saja ungkapan atau cara penafsirannya yang berbeda. ${ }^{25}$

Q.S An-Nisa Ayat 3 membenarkan bagi seorang laki-laki melakukan poligami mulai dari dua, tiga, sampai empat orang isteri, selama ia dapat berlaku adil kepada semua isterinya, namun abila tidak, maka tidak dibenarkan berpoligami dan hanya cukup dengan seorang isteri saja, karena demikian itu lebih mudah baginya dalam berlaku adil. Islam tidak dengan mudah mengizinkan umatnya berpoligami, karena Islam sangat menjunjung tinggi nilai-nilai keadilan dalam keluarga, karena ini menyangkut dengan harkat dan martabat kaum wanita yang mempunyai hak penuh terhadap keadilan suaminya.

Keadilan yang diwajibkan oleh Allah dalam ayat diatas, tidaklah bertentangan dengan firman Allah SWT. Dalam Surat An-Nisa Ayat 129 Artinya : Dan kamu sekalikali tidak akan dapat berlaku adil diantara istri-istri (mu), walupun kamu sangat ingin berbuat demikian, karena itu jangan lah kamu terlalu cenderung (kepada yang kamu cinta), sehingga kamu biarkan yang lain terkatungkatung. (QS. An-Nisa (4):129). Kalau ayat tersebut seolah-olah bertentangan dengan masalah berlaku adil, pada ayat 3 surat AnNisa, diwajibkan berlaku adil, sedangkan ayat 129 meniadakan berlaku adil. Pada hakikatnya, kedua ayat tersebut tidaklah bertentangan karena yang dituntut disini adalah adil dalam masalah lahiriyah bukan kemampuan manusia. Berlaku adil yang ditiadakan dalam ayat diatas adalah adil dalam masalah cinta dan kasih sayang.

Selaras dengan Ketentuan KHI yang menyangkut poligami juga tidak jauh berbeda dengan UU Perkawinan. Hanya saja di dalam KHI dijelaskan antara lain bahwa pria beristeri lebih dari satu diberikan pembatasan, yaitu seorang pria tidak boleh beristeri lebih dari 4 (empat) orang. Selain itu, syarat utama seorang pria untuk mempunyai isteri lebih dari satu adalah pria tersebut harus mampu berlaku adil terhadap isteri-isterinya dan anak-anaknya (Pasal $55 \mathrm{KHI}$ ). Menurut KHI, suami yang hendak beristeri lebih dari satu orang harus mendapatkan izin dari pengadilan agama. Jika perkawinan berikutnya dilakukan tanpa izin dari pengadilan agama, perkawinan tersebut tidak mempunyai kekuatan hukum (Pasal 56 KHI).

Dalam poligami yang dilakukan tanpa izin istri, secara hukum suami yang menikah lagi dan mendapakan izin istri tidak dibenarkan dan merupakan pelanggaran hukum. Dan akibat hukum perkawinan yang dilakukan tanpa izin istri pertama (terdahulu) merupakan batal demi hukum atau dianggap tidak pernah ada. Jadi jelas bahwa bila suami ingin menikah lagi maka wajib mendapakan izin terlebih dahulu dari istri pertama atau istriistri terdahulu, bila tidak mendapkan izin, maka secara hukum pernikahan itu merupakan cacat menurut hukum sehingga batal demi hukum.

Bila suami sudah menikah lagi atau berpoligami tanpa sepengatuan dari istri pertama, maka istri pertama dapat menuntut dengan mengajukan permohonan pembatalan pernikahan yang terdapat didalam Pasal 22-29 Undang-Undang Perkawinan. Pembatalan perkawinan hanya dapat dilakukan dengan putusan pengadilan, sehingga dengan adanya putusan pengadilan sebuah perkawinan yang sudah terjadi dianggap tidak pernah ada.

\section{${ }^{25} \mathrm{~S}$.}


Namun meskipun perkawinan itu sudah di anggap tidak pernah ada, tidak serta merta menghilangkan akibat hukum dalam perkawinan yang pernah dilakukan.

Ketentuan Undang-Undang No 1 tahun 1974 memberikan ulasan tentang alasan tentang dapat dilakukannya pembatalan perkawinan yaitu:

1) Perkawinan dilangsungkan di bawah ancaman yang melanggar hukum (Pasal 27 UU Perkawinan).

2) Salah satu pihak memalsukan identitas dirinya (Pasal 27 UU Perkawinan). Identitas palsu misalnya tentang status, usia, nama atau agama.

3) Suami/istri yang masih mempunyai ikatan perkawinan melakukan perkawinan tanpa seizin dan sepengetahuan pihak lainnya (Pasal 24 UU Perkawinan).

4) Perkawinan yang tidak sesuai dengan syarat-syarat perkawinan (Pasal $22 \mathrm{UU}$ Perkawinan. ${ }^{26}$

Pasal 24 UU No. 1 Tahun 1974 memberikan ketentuan tentang alasan dapat dilakukannya pembatalan perkawinan yaitu suami/istri yang masih mempunyai ikatan perkawinan melakukan perkawinan tanpa seizin dan sepengetahuan pihak lainnya. Sejalan dengan ketentuan UU Perkawinan, Kompilasi Hukum Islam juga telah menyempurnakan terkait dengan pembatalan perkawinan menjadi dua kategori yakni Perkawinan yang batal dengan sendirinya, dan yang dapat dibatalkan.27

Pembatalan Perkawinan dapat terjadi apabila terjadi peristiwa perkawinan sebagai berikut:

1. Perkawinan yang batal dengan sendirinya, yaitu perkawinan yang dilakukan oleh suami, sedangkan ia tidak berhak melakukan akad nikah karena sudah mempunyai empat orang istri, sekalipun salah satu dari keempat istrinya itu dalam iddah talak raj ' $i$, seseorang menikahi bekas istrinya yang telah dili 'annya, seseorang menikahi bekas istrinya yang pernah dijatuhi tiga kali talak olehnya, kecuali bila bekas istri tersebut pernah menikah dengan pria lain yang kemudian bercerai lagi ba 'da addukhul dari pria tersebut dan telah habis masa iddah-nya.

2. Perkawinan yang dilakukan antara dua orang yang mempunyai hubungan darah, semenda, dan sesusuan sampai derajat tertentu yang menghalangi perkawinan menurut Pasal 8 UU Perkawinan, yaitu: berhubungan darah dalam garis keturunan lurus ke bawah atau ke atas, berhubungan darah dalam garis keturunan menyamping yaitu antara saudara, antara seorang dengan saudara orang tua, dan antara seorang dengan saudara neneknya, berhubungan semenda (mertua, anak tiri, menantu, dan ibu atau ayah tiri), berhubungan sesusuan (orang tua sesusuan, anak sesusuan, saudara sesusuan, dan bibi atau paman sesusuan), istri adalah saudara kandung atau sebagai bibi atau kemenakan dari istri atau istri-istrinya.

3. Perkawinan yang dapat dibatalkan adalah perkawinan poligami yang dilakukan oleh seorang suami tanpa adanya izin pengadilan agama, atau perkawinan yang telah berlangsung dan akan tetapi perempuan yang dikawini ternyata kemudian diketahui masih menjadi istri pria lain yang mafqud atau perempuan yang dikawini ternyata

\footnotetext{
${ }^{26}$ Siregar, "Sanksi Pidana Terhadap Perkawinan Poligami Tanpa Adanya Persetujuan Istri."

${ }^{27}$ Siregar.
} 
masih dalam iddah dari suami lain. Selanjutnya perkawinan yang melanggar batas umur perkawinan sebagaimana yang telah ditetapkan dalam Pasal 7 UU Perkawinan, perkawinan dilangsungkan tanpa wali atau dilaksanakan oleh wali yang tidak berhak dan perkawinan yang dilaksanakan dengan paksaan..$^{28}$

Pembataan perkawinan tentu dapat dipastikan masuk dalam area hukum acara atau hukum formal sehingga lahir suatu putusan pengadilan. Karena putusan pengadilan ini merupakan peristiwa hukum akibat dari perbuatan hukum terhadap suatu perkawinan orang lain, bukan putusan terjadina perceraian. Perbuatan hukum yang dimaksud ini merupan pengajuan permohonan pembatalan perkawinan yang diajukan oleh pihak yang mempunyai hak sebagaimana ditentukan dalam Pasal 23 UU No. 1 Tahun 1974 ditegaskan bahwa yang dapat mengajukan pembatalan perkawinan yaitu:

a. Para keluarga dalam garis keturunan lurus keatas dari suami dan isteri.

b. Suami isteri.

c. Pejabat yang berwenang hanya selama perkawinan belum diputuskan.

d. Pejabat yang diunjuk tersebut ayat (2) pasal 16 Undang-Undang ini dan setiap orang yang mempunyai kepentingan hukum secara langsung terhadap perkawinan tersebut, tetapi hanya setelah perkawinan itu putus.

Pembatalan perkawinan hanya dapat dilakukan bila terjadi pelanggaran sebagaimana ditentukan dalam Pasal 22, 24, 26, dan 27 UU No. 1 Tahun 1974. Proses pembatalan perkawinan sama dengan tata cara gugatan perceraian, baik itu pemanggilan, pemeriksaan dan putusan pembatalan pernikahan perkawinan poligami, sebagaimana yang diatur dalam Pasal 20 sampai 306 PP No. 9 Tahun 1975. Pembatalan perkawinan yang di lakukan oleh istri terhadap suami yang menikah lagi tanpa izin istri, tidak ada batas waktunya dalam melakukan proses pembatalan perkawinan dan kapanpun istri dapat mengajukan permohonan pembatalan perkawinan.

Ada beberapa akibat hukum terhadap perkawinan poligami tanpa adanya persetujuan dari istri yang sah, pertama akibat hukum yang akan berimplikasi bagi istri kedua atau selanjutnya, dan kedua akibat hukum yang akan berimplikasi terhadap lakilaki yang telah melangsungkan perkawinan poligami tersebut. Implikasi hukum tersebut pula dapat dilihat dari beberapa aspek, baik dari aspek hukum administrasi / perdata, juga dari aspek hukum pidana.

Akibat hukum yang akan berimplikasi bagi istri kedua atau selanjutnya juga terbagi kepada dua bagian, pertama perkawinan poligami yang telah dicatatkan di kantor urusan agama atau catatan sipil, kedua perkawinan poligami yang tidak dicatatkan di kantor urusan agama atau catatan sipil. Perkawinan poligami yang telah dicatatkan di kantor urusan agama atau catatan sipil akan berimplikasi terhadap akan terjadinya pembatalan perkawinan melalui pengadilan agama/pengadilan negeri manakala jika pihak kantor urusan agama telah mengeluarkan akta nikah untuk yang kedua atau kesekian kalinya.

Selanjutnya perkawinan poligami yang tidak dicatatkan di kantor urusan agama atau catatan sipil akan berimplikasi terhadap aspek hukum administrasi yaitu kedudukan

${ }^{28}$ Siregar. 
istri yang tidak mempunyai kekuatan hukum untuk melakukan gugatan terhadap suami bila suatu saat suami menceraikannya, harta gono-gini, serta hak pembiayaan terhadap anaknya. Konsekuensi lainnya adalah, bahwa seorang anak akan tidak mempunyai akta kelahiran yang dicatatkan di catatan sipil yang menunjukkan bahwa anak tersebut adalah lahir dari perkawinan yang sah yang pada akhirnya seorang anak hanya mempunyai pertalian hukum dengan ibunya saja yang juga berakibat seorang anak tidak akan mendapatkan warisan dari ayahnya tersebut, karena tidak adanya catatan hukum yang menghubungkan dari keduanya.

Kompilasi Hukum Islam memberikan penjelasan tentang tatacara untuk melakukan pembatalan perkawinan. Suatu perkawinan dapat dikatakan batal setelah adanya putusan pengadilan Agama yang mempunyai kekuatan hukum yang tetap dan berlaku sejak saat berlangsungnya perkawinan. Pasal 37 Peraturan Pemerintah Nomor 9 tahun 1975 tentang Pelaksanaan Undang-Undang Perkawinan tentang perkawinan juga menegaskan bahwa batalnya suatu perkawinan hanya dapat diputuskan oleh pengadilan.

Selanjutnya ketentuan Pasal 25 UU Perkawinan \& Pasal 74 Kompilasi Hukum Islam menegaskan bahwa pembatalan perkawinan dapat dilakukan dengan cara mengajukan permohonan pembatalan perkawinan kepada pengadilan/pengadilan agama yang mewilayahi tempat tinggal suami atau isteri atau tempat perkawinan dilangsungkan.

Pasal 38 Ayat (2) Peraturan Pemerintah Nomor 9 tahun 1975 tentang Pelaksanaan Undang-Undang Nomor 1 Tahun 1974 menegaskan bahwa tata cara pengajuan permohonan pembatalan perkawinan dilakukan sesuai dengan tata cara pengajuan gugatan perceraian. Gugatan pembatalan perkawinan diajukan oleh pihak yang berwenang atau kuasanya kepada pengadilan yang daerah hukumnya meliputi tempat kediaman tergugat.

Akibat dari suami melanggar perjanjian perkawinan poligami dalam hal tidak memberikan nafkah kepada isteri dan anak mereka serta tidak dapat berbuat adil, maka dalam Undang-undang Perkawinan Nomor 1 Tahun 1974 Pasal 1 menegaskan bahwa suami wajib melindungi isteri dan memberikan segala sesuatu keperluan hidup berumah tangga sesuai dengan kemampuannya. Sedangkan dalam Kompilasi Hukum Islam (KHI) Pasal 80 ayat 4 menjelaskan bahwa suami dengan penghasilannya menanggung : nafkah, kiswah termpat kediaman bagi isteri, biaya rumah tangga, dan pendidikan anak.

Dari aturan tersebut isteri dapat memuntut suami apabila melanggar perjanjian dan tidak berbuat adil dari perkawinan poligami yaitu dengan mengganti pembiayaan nafkah yang tidak diberikan selama perkawinan. Suatu hukum yang menyangkut tentang kewajiban pasti terdapat implikasi bagi hukum yang dilanggar. Hakim dapat menentukan pembayaran nafkah tersebut. Apabila keputusan-keputusan majelis hakim tidak dipenuhi oleh tergugat, maka panitera dan juru sita pengadilan agama dapat mengeksekusi dengan cara menyita harta tergugat setelah keputusan tersebut mempunyai kekuatan hukum.

Jadi secara umum, konsekuensi bagi suami yang melaksanakan poligami yang melanggar aturan hukum positif dan hukum islam dapat diuraikan sebagai berikut: 
a. Perkawinan poligami tersebut tidak mempunyai kekuatan hukum, karena perkawinan tersebut dianggap tidak pernah telah ada (wujuduhu ka adamihi), sehingga tidak menimbulkan akibat hukum;

b. Tidak dapat dijadikan dasar untuk suatu kepentingan hukum secara legal-formal atas segala hal-hal yang menyangkut hubungan hukum dari perkawinan itu.

c. Apabila dalam perkawinan tersebut menimbulkan sengketa di kemudian hari, maka perkawinan tersebut tidak dapat dijadikan dasar untuk semua tuntutan hukum ke Pengadilan.

d. Tidak dapat dijadikan dasar untuk menuntut hak-hak suami isteri termasuk anak-anak mereka secara legal-formal dalam kehidupan bernegara maupun dalam pergaulan sosial kemasyarakat.

Berbagai hak seorang isteri harus dipenuhi oleh suami agar tidak lahir intimidasi dan perlakuan yang semena-mena. Walaupun dalam peraturan perundang-undangan maupun Al-Qur'an di atas mengandung konsep poligami, hal ini bukan berarti Islam menganjurkan umatnya poligami, akan tetapi merupakan suatu pintu yang amat sempit yang hanya dapat dilakukan pada saat darurat saja. Sampai saat ini hukum positif di Indonesia tentang poligami masih sangat relevan diterapkan dalam rangka perlindungan hukum bagi istri, serta guna kepastian hukumnya.

\section{E. PENUTUP}

Hukum positif telah menyinggung bahwasannya dalam hal suami hendak meminta izin poligami harus mendapatkan persetujuan oleh istri dan pengadilan. Perkawinan dianggap tidak sah atau batal demi hukum apabila suami dalam berpoligami melanggar aturan hukum positif, sehingga dikhawatirkan di kemudian hari pernikahan poligami tersebut tidak memiliki kekuatan hukum. Konsekuensi perkawinan tersebut selanjutnya akan menjadi lebih rumit, karena segala akibat hukum dari hubungan perkawinan itu juga dianggap tidak ada. Bila suami sudah menikah lagi atau berpoligami tanpa sepengatuan dari istri pertama, maka istri pertama dapat menuntut dengan mengajukan permohonan pembatalan pernikahan. Selain itu, apabila seorang suami melakukan perkawinan poligami di luar prosedur yang telah ditetapkan dalam Undang-undang Perkawinan, maka perbuatan tersebut merupakan suatu perbuatan pidana yang bertentangan dengan Pasal 279 KUHP. Sedangkan dalam konsekuensi hukum Islam, pada dasarnya Islam tidak melarang apabila suami melaksanakan poligami, kecuali hanya memberikan syarat kepada suami untuk berlaku adil dan tidak melebihi dari empat istri. Jika melanggar dari ketentuan tersebut makanya hukumnya haram.

\section{DAFTAR PUSTAKA}

Alimuddin. Aplikasi Pembaharuan Hukum Dalam Teori Socio Legal Studies, DitJen Badan Peradilan, 2014. www.badilag.net.

Ardhian, Reza Fitra, Satrio Anugrah, and Bima Setyawan. "Poligami Dalam Hukum Islam Dan Hukum Positif Indonesia Serta Urgensi Pemberian Izin Poligam Di 
Pengadilan Agama." Privat Law 3, no. 2 (2015): 100-107. file:///C:/Users/Klinikcomp/Downloads/Documents/164461-ID-poligami-dalamhukum-islam-dan-hukum-pos.pdf.

Azni, Azni. "Izin Poligami Di Pengadilan Agama (Suatu Tinjauan Filosofis)." Jurnal Dakwah Risalah 26, no. 2 (2015): 55-68. https://doi.org/10.24014/jdr.v26i2.1214. KBBI Online. "Kamus Besar Bahasa Indonesia," n.d. https://kbbi.web.id/.

Manan, Bagir. Hukum Positif Indonesia: Satu Kajian Teoritik. Yogyakarta, Indonesia: FH UII Press, 2004.

Mustofa, M A. "Poligami Dalam Hukum Agama Dan Negara." AL-IMARAH: Jurnal Pemerintahan Dan Politik Islam 2, no. 01 (2017): 47-58. https://ejournal.iainbengkulu.ac.id/index.php/alimarah/article/view/1029.

Raflisman. "Sanksi Hukum Poligami Tanpa Izin Pengadilan Agama Dalam Kitab Undang-Undang Hukum Pidana Ditinjau Dari Hukum Islam.” QIYAS Vol. 1, No. 1, April 2016 1, no. 1 (2016).

Rizkal, Rizkal. "Poligami Tanpa Izin Isteri Dalam Perspektif Hukum: Bentuk Kekerasan Psikis Terhadap Isteri." Jurnal Yustika: Media Hukum Dan Keadilan 22, no. 01 (2019): 26-36. https://doi.org/10.24123/yustika.v22i01.2017.

Roslinda, Sri, Bunyamin Alamsyah, and Fredricka Nggeboe. "Penerapan Sanksi Pidana Terhadap Pelaku Perkawinan Poligami Dalam Persfektif Perundang-Undangan Indonesia." Legalitas: Jurnal Hukum 11, no. 1 (2019): 27. https://doi.org/10.33087/legalitas.v11i1.168.

S, Riyandi. "Syarat Adanya Persetujuan Isteri Untuk Berpoligami (Analisis Ushul Fikih Syafi'İyyah Terhadap Undang-Undang Perkawinan Nomor 1 Tahun 1974)." Ilmiah, Jurnal Futura, Islam 15, no. 1 (2015): 111-42.

Shomad, Abd. Hukum Islam: Penormaan Prinsip Syariah Dalam Hukum Indonesia. Jakarta: Kencana Prenada Media Group., 2010.

Siregar, Muhammad Yusuf. "Sanksi Pidana Terhadap Perkawinan Poligami Tanpa Adanya Persetujuan Istri." Jurnal Ilmiah Advokasi 5, no. 01 (2017).

Ulfiyati, Nur Shofa. "Izin Isteri Sebagai Syarat Poligami Perspektif Hak Asasi Manusia : Kajian Terhadap Undang-Undang Perkawinan" 8, no. 2 (2016): 97-112.

Alimuddin. Aplikasi Pembaharuan Hukum Dalam Teori Socio Legal Studies, DitJen Badan Peradilan, 2014. www.badilag.net.

Ardhian, Reza Fitra, Satrio Anugrah, and Bima Setyawan. "Poligami Dalam Hukum Islam Dan Hukum Positif Indonesia Serta Urgensi Pemberian Izin Poligam Di Pengadilan Agama." Privat Law 3, no. 2 (2015): 100-107. file:///C:/Users/Klinikcomp/Downloads/Documents/164461-ID-poligami-dalamhukum-islam-dan-hukum-pos.pdf.

Azni, Azni. "Izin Poligami Di Pengadilan Agama (Suatu Tinjauan Filosofis)." Jurnal Dakwah Risalah 26, no. 2 (2015): 55-68. https://doi.org/10.24014/jdr.v26i2.1214.

KBBI Online. "Kamus Besar Bahasa Indonesia," n.d. https://kbbi.web.id/.

Manan, Bagir. Hukum Positif Indonesia: Satu Kajian Teoritik. Yogyakarta, Indonesia: FH UII Press, 2004.

Mustofa, M A. "Poligami Dalam Hukum Agama Dan Negara." AL-IMARAH: Jurnal Pemerintahan Dan Politik Islam 2, no. 01 (2017): 47-58. https://ejournal.iainbengkulu.ac.id/index.php/alimarah/article/view/1029.

Raflisman. "Sanksi Hukum Poligami Tanpa Izin Pengadilan Agama Dalam Kitab 
Undang-Undang Hukum Pidana Ditinjau Dari Hukum Islam.” QIYAS Vol. 1, No. 1, April 2016 1, no. 1 (2016).

Rizkal, Rizkal. "Poligami Tanpa Izin Isteri Dalam Perspektif Hukum: Bentuk Kekerasan Psikis Terhadap Isteri." Jurnal Yustika: Media Hukum Dan Keadilan 22, no. 01 (2019): 26-36. https://doi.org/10.24123/yustika.v22i01.2017.

Roslinda, Sri, Bunyamin Alamsyah, and Fredricka Nggeboe. "Penerapan Sanksi Pidana Terhadap Pelaku Perkawinan Poligami Dalam Persfektif Perundang-Undangan Indonesia." Legalitas: Jurnal Hukum 11, no. 1 (2019): 27. https://doi.org/10.33087/legalitas.v11i1.168.

S, Riyandi. "Syarat Adanya Persetujuan Isteri Untuk Berpoligami (Analisis Ushul Fikih Syafi'İyyah Terhadap Undang-Undang Perkawinan Nomor 1 Tahun 1974).” Ilmiah, Jurnal Futura, Islam 15, no. 1 (2015): 111-42.

Shomad, Abd. Hukum Islam: Penormaan Prinsip Syariah Dalam Hukum Indonesia. Jakarta: Kencana Prenada Media Group., 2010.

Siregar, Muhammad Yusuf. "Sanksi Pidana Terhadap Perkawinan Poligami Tanpa Adanya Persetujuan Istri." Jurnal Ilmiah Advokasi 5, no. 01 (2017).

Ulfiyati, Nur Shofa. "Izin Isteri Sebagai Syarat Poligami Perspektif Hak Asasi Manusia : Kajian Terhadap Undang-Undang Perkawinan" 8, no. 2 (2016): 97-112.

Alimuddin. Aplikasi Pembaharuan Hukum Dalam Teori Socio Legal Studies, DitJen Badan Peradilan, 2014. www.badilag.net.

Ardhian, Reza Fitra, Satrio Anugrah, and Bima Setyawan. "Poligami Dalam Hukum Islam Dan Hukum Positif Indonesia Serta Urgensi Pemberian Izin Poligam Di Pengadilan Agama." Privat Law 3, no. 2 (2015): 100-107. file:///C:/Users/Klinikcomp/Downloads/Documents/164461-ID-poligami-dalamhukum-islam-dan-hukum-pos.pdf.

Azni, Azni. "Izin Poligami Di Pengadilan Agama (Suatu Tinjauan Filosofis)." Jurnal Dakwah Risalah 26, no. 2 (2015): 55-68. https://doi.org/10.24014/jdr.v26i2.1214.

KBBI Online. "Kamus Besar Bahasa Indonesia," n.d. https://kbbi.web.id/.

Manan, Bagir. Hukum Positif Indonesia: Satu Kajian Teoritik. Yogyakarta, Indonesia: FH UII Press, 2004.

Mustofa, M A. "Poligami Dalam Hukum Agama Dan Negara." AL-IMARAH: Jurnal Pemerintahan Dan Politik Islam 2, no. 01 (2017): 47-58. https://ejournal.iainbengkulu.ac.id/index.php/alimarah/article/view/1029.

Raflisman. "Sanksi Hukum Poligami Tanpa Izin Pengadilan Agama Dalam Kitab Undang-Undang Hukum Pidana Ditinjau Dari Hukum Islam." QIYAS Vol. 1, No. 1, April 2016 1, no. 1 (2016).

Rizkal, Rizkal. "Poligami Tanpa Izin Isteri Dalam Perspektif Hukum: Bentuk Kekerasan Psikis Terhadap Isteri." Jurnal Yustika: Media Hukum Dan Keadilan 22, no. 01 (2019): 26-36. https://doi.org/10.24123/yustika.v22i01.2017.

Roslinda, Sri, Bunyamin Alamsyah, and Fredricka Nggeboe. "Penerapan Sanksi Pidana Terhadap Pelaku Perkawinan Poligami Dalam Persfektif Perundang-Undangan Indonesia." Legalitas: Jurnal Hukum 11, no. 1 (2019): 27. https://doi.org/10.33087/legalitas.v11i1.168.

S, Riyandi. "Syarat Adanya Persetujuan Isteri Untuk Berpoligami (Analisis Ushul Fikih Syafi'Īyyah Terhadap Undang-Undang Perkawinan Nomor 1 Tahun 1974).” Ilmiah, Jurnal Futura, Islam 15, no. 1 (2015): 111-42. 
Shomad, Abd. Hukum Islam: Penormaan Prinsip Syariah Dalam Hukum Indonesia. Jakarta: Kencana Prenada Media Group., 2010.

Siregar, Muhammad Yusuf. "Sanksi Pidana Terhadap Perkawinan Poligami Tanpa Adanya Persetujuan Istri." Jurnal Ilmiah Advokasi 5, no. 01 (2017).

Ulfiyati, Nur Shofa. "Izin Isteri Sebagai Syarat Poligami Perspektif Hak Asasi Manusia : Kajian Terhadap Undang-Undang Perkawinan” 8, no. 2 (2016): 97-112. 